Paweł Janik

Uniwersytet Warszawski, Warszawa

\title{
Amazonki - \\ mit czy reminiscencja zwyczajów koczowników
}

Motyw niezależnych, wojowniczych kobiet był obecny w kulturze greckiej co najmniej od czasów archaicznych, by później zostać przejęty przez Rzymian i ludzi średniowiecza. O Amazonkach wspominał już w Iliadzie Homer (Hom., Il. III. 52-55, VI. 186). Miało to być plemię złożone wyłącznie z kobiet, które zamieszkiwało rejon Pontu. W celu przedłużenia rodu jego członkinie miałyby obcować z sąsiednim plemieniem Gargarów (Str. XI. 1-2, 5) bądź też z innymi mężczyznami. Gdy z takiego związku urodził się chłopiec, zabijano go lub oddawano ojcu. W przypadku narodzin córki, przyjmowano ją do społeczności i wychowywano na wojowniczkę. Jasne jest, że taka społeczność nigdy nie istniała, jednakże tak jak w przypadku wielu mitów, legenda Amazonek może mieć praźródło w rzeczywistości historycznej. Wydawałoby się, że mit Amazonek mógł zrodzić się z podświadomego strachu społeczeństwa wybitnie patriarchalnego, jakim byli starożytni Grecy, a później (choć w trochę mniejszym stopniu) Rzymianie, przed wyzwolonymi, niezależnymi kobietami. $\mathrm{Z}$ jednej strony mogła to być obawa, a z drugiej rodzaj fantazjifetyszu, podobnego do widowiskowych walk gladiatrices (kobietgladiatorów) w czasach rzymskich (Brunet 2014: 478-491) (Il. 1). Wszystkie te odczucia mogły bez wątpienia wpłynąć na krystalizowanie się legend o Amazonkach, jednakże wiele wskazuje na to, że 
do formowania się ich mitu przyczyniły się w znacznym stopniu również obserwacje pewnych zwyczajów irańskojęzycznych nomadów, zamieszkujących północne wybrzeże Morza Czarnego i Azję Środkową. Grecy, przybywając i następnie osiedlając się na tych terenach, wchodzili $\mathrm{w}$ różnorakie relacje $\mathrm{z}$ tamtejszymi mieszkańcami. Widzieli różnorodne zachowania i tradycje lokalnej ludności, których mogli nie rozumieć lub źle zinterpretować. Następnie swoje spostrzeżenia (przepuszczone na dodatek przez filtr ich własnej kultury) przekazywali dalej w głąb greckiej ekumeny. Tam, ulegając dalszym przeinaczeniom i transformacji, mogły one dać podwaliny lub wpłynąć na kształtowanie się mitu Amazonek. Mimo że wyobrażenia i przekazy o owych wojowniczych kobietach ewoluowały z czasem, to związek z irańskojęzycznymi nomadami, takimi jak Scytowie, Sarmaci czy Massageci, wydaje się oczywisty. To właśnie ów związek jest tematem niniejszego artykułu. Temat ten był już wielokrotnie poruszany (Mayor 2014), jednak nie doczekał się całościowego opracowania. Niniejsza praca ma za zadanie podsumować dotychczasową wiedzę w zwięzły sposób, dodając jednocześnie nowe elementy.

Do niedawna dominował pogląd, że nazwa „Amazonki” (gr. 'A $\mu \alpha-$

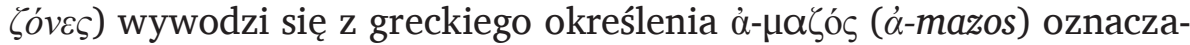
jącego „bez piersi”. Jej źródłem miało być przekonanie, jakoby Amazonki usuwały sobie prawe piersi, by lepiej strzelać z łuku (Epitome II: 4), aczkolwiek w sztuce przedstawiano je raczej z obiema piersiami. Istnieje również przypuszczenie, że nazwa ta ma irański źródłosłów i może pochodzić od słowa hamazakaran, oznaczającego „wojować” . W tym kontekście wyraz „Amazonki” miałby oznaczać po prostu „wojowniczki”. Być może pierwotnie w ten sposób irańskojęzyczni nomadzi określali kobiety, które brały udział w walce, i to właśnie $\mathrm{z}$ tego wyewoluowała nazwa rzekomego plemienia i sam mit Amazonek. Jeśli chodzi o nazewnictwo, warto dodać, że według Herodota Scytowie w swoim języku określali Amazonki mianem Oiorpata, czyli „mężobójczynie” (Hdt. IV. 110). Także w sztuce greckiej Amazonki były często przedstawiane w stroju scytyjskim bądź w strojach innych irańskojęzycznych koczowników. Takie przedstawienia pojawiają się na ceramice zarówno $w$ malarstwie czarnofigurowym, jak i czerwonofigurowym (Il. 2.A-B). Amazonki były dość popularnym tematem w sztuce greckiej, występującym nie tylko na ceramice, ale również w rzeźbie i reliefie. Popularnym motywem była tzw. Amazonoma-

${ }^{1}$ Słowo to (pochodzenia perskiego) zostało zawarte w leksykonie Hezychiusza z Aleksandrii (Frisk 1970: 278) i jest prawdopodobnie związane z irańskim ha-mazan (wojownicy). 
chia, czyli walki Amazonek z Grekami i helleńskimi herosami, jak Herakles czy Achilles (Bothmer 1957). Nie tylko irański strój w ikonografii łączył Amazonki z koczownikami Wielkiego Stepu. Przedstawiano je często jako wojowniczki na koniach oraz łuczniczki, a jednym z ich atrybutów była tarcza typu pelta. Takich samych tarcz używali Scytowie (Il. 3). Amazonki nierzadko też dzierżyły łuki refleksyjne, gorytosy ${ }^{2}$ oraz czekany typu sagaris - uzbrojenie typowo scytyjskie.

Jednak w kwestii związku Amazonek z irańskimi nomadami najwięcej światła rzucają źródła pisane - przede wszystkim czwarta księga Dziejów Herodota. Według Ojca Historii irańskojęzyczny lud Sauromatów (najprawdopodobniej byli to wcześni Sarmaci) zrodził się ze związków Amazonek i Scytów. Oto fragmenty tej wzmianki:

...O Sauromatach taka krąży wieść. Kiedy Hellenowie prowadzili wojnę z Amazonkami (Amazonki nazywają Scytowie Oiorpata, co znaczy „mężobójczynie”, bo oior nazywa się u nich mąż, a pata zabijać), wtedy wedle podania Hellenowie, odniósłszy zwycięstwo w bitwie nad Termodontem, odpłynęli na trzech okrętach z wszystkimi Amazonkami, jakie zdołali żywcem pochwycić; te jednak na pełnym morzu rzuciły się na mężów i wymordowały ich. Ale ponieważ nie znały się na okrętach i nie umiały posługiwać się ani sterem, ani żaglem, ani wiosłem, więc po wycięciu mężczyzn gnane były falą i wiatrem, aż dostały się do Kremnoj nad Jeziorem Meockim. Kremnoj należy do ziemi wolnych Scytów. Tu wysiadły Amazonki z okrętów i ruszyły pieszo do zamieszkałego kraju. Napotkawszy pierwsze stado koni, porwały je, dosiadły i łupiły dobytek Scytów [...] I któryś z nich przyczepił się do jednej z osamotnionych, a Amazonka nie odepchnęła go od siebie, lecz zgodziła się na stosunek. Mówić wprawdzie nie mogła (bo wzajemnie się nie rozumieli), ale ręką wskazała mu, żeby nazajutrz przyszedł na to samo miejsce i innego z sobą przywiódł, przy czym dawała do zrozumienia, że ma ich być dwóch, a ona jeszcze drugą przyprowadzi [...] Skoro jednak pragniecie nas mieć za żony, więc razem z nami to uczyńcie: nuże, wyjdźmy z tej ziemi, przeprawmy się przez rzekę Tanais i tam zamieszkamy. - I w tym także usłuchali ich młodzi. Przeszli tedy przez Tanais i odbyli drogę trzydniową na wschód od tej rzeki, a potem również trzydniową od Jeziora Meockiego na północ. Skoro zaś przybyli na to miejsce, gdzie jeszcze teraz mieszkają, założyli tam swoje siedziby. I odtąd kobiety Sauromatów zachowują dawny swój tryb życia, wyjeżdżając konno na

\footnotetext{
${ }^{2}$ Połączenie sajdaka (etui na łuk) oraz kołczanu (pojemnika na strzały).
} 
łowy wraz z mężami lub bez mężów oraz wvruszaiąc na wojnę i nosząc te same szaty co mężczyźni... (Hdt. IV. 110, 113).

W dalszej części Herodot opisuje lud Sauromatów:

...Sauromaci posługują się językiem scytyjskim, którym jednak od dawien dawna czysto nie mówią, ponieważ Amazonki dobrze się go nie wyuczyły. Co do zaślubin taki u nich panuje zwyczaj. Żadna dziewica nie wyjdzie wprzód za mąż, aż zabije któregoś z nieprzyjaciół. Niektóre z nich nawet umierają jako staruszki, nie wyszedłszv za mąż, ponieważ nie mogły zadośćuczynić prawu.... (Hdt. IV. 116-117).

Także według Pseudo-Skylaksa „...Ludem Sauromatów rządzą kobiety..." (Scyl. 70). Choć powyższe przekazy były bardzo przesadzone, mogą one wskazywać, że kobiety w społecznościach sarmackich koczowników rzeczywiście miały o wiele wyższy status społeczny niż u starożytnych Greków. Twierdzenie to jest na tyle uzasadnione, że jeszcze do niedawna u wielu pasterskich ludów irańskich, jak Basseri lub Bahtiari, kobieta ma o wiele wyższą pozycję społeczną niż u większości otaczających ich osiadłych społeczności muzułmańskich (Edmonds 2010: 188). To, że kobiety Sauromatów mogły jeździć konno na polowania i brać udział w walce (zapewne jednak w ograniczonej formie), było dla helleńskich obserwatorów czymś niebywałym. Według Ojca Historii także wśród scytyjskiego ${ }^{3}$ ludu Issedonów traktuje się kobiety na równi z mężczyznami (Hdt. IV. 28).

Kolejnym rodzajem źródeł świadczących o tym, że mit o Amazonkach mógł wyrosnąć z obserwacji zwyczajów ludów irańskich, są materiały archeologiczne. Zagadnienie to dobrze obrazują m.in. wyniki badań zespołu cmentarzysk z Pokrovki w Kazachstanie, które są datowane od okresu sauromackiego do późnosarmackiego (od VI w. p.n.e. do III w. n.e.). Jeannine Davis-Kimball - badaczka, która analizowała tamtejsze praktyki pogrzebowe, spośród grobów kobiecych wydzieliła trzy specyficzne grupy odstające od zwykłych, niewyróżniających się pochówków. Były to groby: tzw. „kapłanek”, które stanowiły ok. 7\% wszystkich mogił kobiecych; „wojowniczek”, których było ok. 2,15\%, oraz „kapłanek-wojowniczek”, których było najmniej. Pierwsza grupa wyróżniała się występowaniem w inwentarzu grobowym plakietek zoomorficznych, pedantów wotywnych, skamieniałych muszli morskich, brązowych luster oraz kamiennych lub

${ }^{3}$ Użycie wyrazu „scytyjski” miało prawdopodobnie znaczyć, że Issendonowie również byli irańskojęzycznymi nomadami. 
glinianych ołtarzyków. Przykładem mogą być pochówek 3 z kurhanu 3 oraz pochówek 6 z kurhanu 7 na cmentarzysku nr $2^{4}$. Druga grupa została wyróżniona na podstawie występowania w grobach uzbrojenia, jak np. grotów strzał oraz włóczni, noży, mieczy i kołczanów. Do takich pochówków można zaliczyć m.in. grób 1 z kurhanu 7 oraz grób 5 z kurhanu 8 na cmentarzysku nr 2. Natomiast ostatnia kategoria pochówków charakteryzowała się tym, że łączyła elementy dwóch poprzednich klas. Do tego typu mogił można zaliczyć groby 4 z kurhanów 7 i 8 na cmentarzysku nr 2. Ciekawostką jest to, że na tamteis7.vm cmentarzysku szczątki małych dzieci towarzyszyły ok. 3\% grobów męskich, natomiast nie stwierdzono towarzyszących pochówków dziecięcych przy mogiłach kobiecych (Davis-Kimball 1997: 4448). Występowanie broni w pochówkach kobiecych w Pokrovce nie jest niczym wyjątkowym dla kultury sauromackiej czy nawet scytyjskiej. Dużo wskazuje na to, że było to zjawisko nieobejmujące wprawdzie większości grobów kobiecych, ale nierzadkie (Chochorowski 1999: 341). Oczywiście, nie możemy w sposób definitywny potwierdzić, że powyższe kobiety za życia parały się sztuką wojenną lub czy kiedykolwiek w ogóle walczyły. Być może wkładanie do grobów broni wiązało się z praktykami wykraczającym poza naszą percepcję. Jednakże występowanie uzbrojenia $\mathrm{w}$ grobach kobiecych w połączeniu ze źródłami pisanymi jest zastanawiające. Nie oznacza to naturalnie, że istniał twór na wzór mitycznych Amazonek, ani nawet nie musi to świadczyć, że wśród irańskojęzycznych nomadów istniały specjalne oddziały kobiece, ani że zwyczaj noszenia broni przez kobiety był powszechny. Niemniej jednak, powyższe przesłanki wskazują, że do takich sytuacji mogło dochodzić i możliwe, że kobiety ówczesnych koczowników (przynajmniej niektórych ich grup) miały prawo wziąc udział $\mathrm{w}$ walce i posiadały lepszą pozycję społeczną niż większość kobiet ze świata antycznego, co mogło być jednym ze źródeł mitu o Amazonkach.

Oprócz Amazonek źródła pisane wymieniają również inną klasę niezależnych kobiet łączonych z żywiołem koczowniczym - królowe, lecz nie żony królów, tylko samodzielne władczynie. Na początku należy wspomnieć o sakijskiej ${ }^{5}$ królowej Sparetrze wymienionej przez Ktezjasza (Ctes. 33-39). Gdy król perski Cyrus Wielki wydał wojnę Sakom i wziął do niewoli ich króla - Amorgesa, to Sparetra ruszyła na

\footnotetext{
${ }^{4}$ Według niektórych badaczy Amazonki były łączone z kultem płodności oraz Matką Ziemią / Matką Bogów (Rostovtzev 1918: 81; Guliaev 2003: 121-123).

${ }^{5}$ Sakowie - przypuszczalnie była to wschodnia gałąź Scytów bądź zbiorcze określenie irańskojęzycznych nomadów.
} 
pomoc swemu mężowi na czele oddziałów złożonych zarówno z kobiet, jak i mężczyzn. Pokonawszy Cyrusa, wzięła go do niewoli. Następnie w zamian za uwolnienie męża oswobodziła króla perskiego.

Kolejną wojowniczą władczynią związaną z Cyrusem Wielkim była królowa Massagetów Tomyris, wspomniana przez Herodota:

... Gdy zatem Cyrus i ten lud podbił, zapragnął on także Massagetów pod władzę swą dostać. Lud ten ma być wielki i silny, a mieszka ku wschodowi i wzejściu słońca, z tamtej strony rzeki Arakses i naprzeciw ludu Issedonów. Niektórzy też utrzymują, że jest to lud scytyjski [...] Królową Massagetów była po śmierci męża kobieta; na imię było jej Tomyris. Do niej posłał Cyrus i pozornie zabiegał, jakoby chciał ją mieć za żonę. Ale Tomyris, która dobrze wiedziała, że zabiega on nie o nią samą, tylko o panowanie nad Massagetami, nie godziła się na jego przybycie. Gdy więc Cyrusowi nie udał się podstęp, pomaszerował następnie nad Arakses i jawnie rozpoczął wyprawę przeciw Massagetom, sprzęgając mosty okrętowe na rzece dla przeprawienia wojska i buduịac wieże na statkach, które służyły do przejścia przez rzekę... (Hdt. I. 201, 204).

W czasie wyprawy Cyrus miał zabić syna królowej Massagetów. Ostatecznie Tomyris pomściła go, zabijając Cyrusa, jednakże trudno stwierdzić, czy owe wydarzenia miały w rzeczywistości miejsce. Być może postacie Sparetry i Tomyris to ta sama osoba - jakaś charyzmatyczna królowa koczowników, która w bliżej nieokreślony sposób upokorzyła władcę perskiego. Jednakże inne imiona, inne postaci poboczne (w jednej mąż, w drugiej syn) oraz całkowicie rozbieżne zakończenia sugerują, że mogły to być dwa oddzielne epizody lub legendy. Warta zwrócenia uwagi jest wzmianka, że Sparetra wzięła ze sobą oddziały złożone zarówno z mężczyzn, jak i kobiet.

Podobną wojowniczą władczynią nomadów była Zarina. Znamy jej postać głównie dzięki przekazowi Mikołaja z Damaszku (Nic.Dam., FgrHist. 90, F5). Otóż owa Zarina była królową Saków, żoną króla Marmareusa, która wraz ze swym małżonkiem wyruszała na wojny i osobiście brała udział w walce. Pewnego razu podczas starcia z Medami, Zarina została ranna i pojmana przez króla medyjskiego Stryangaiosa. Był on zaskoczony, że pod zbroją skrywała się piękna kobieta. Zarina zdołała przekonać go, by ją uwolnił. W późniejszym czasie Stryangaios sam znalazł się w niewoli króla Marmareusa. Zarina błagała męża, by oszczędził władcę Medów, ten jednak nie chciał jej słuchać. Zarina zabiła swego męża, ratując Stryangaiosa - tak rozpoczął się ich romans. 
Znana jest także na wpół legendarna wzmianka przekazana przez Poliajnosa, dotycząca królowej Sarmatów - Amage, żony niedołężnego sarmackiego władcy Medosakkesa. Miała ona wraz z 120 doborowymi wojownikami pomóc obleganemu przez Scytów Chersonezowi Taurydzkiemu. Według przekazu Amage zabiła scytyjskiego króla, jego krewnych i przyjaciół, oswobodziła terytoria chersoneskie, a władzę nad Scytami przekazała synowi zabitego władcy (Polyaen. VIII. 56). Być może podobne charyzmatyczne przywódczynie nomadów stały się pierwowzorami legendarnych królowych Amazonek, jak np. Hippolita (D.S. II. 5, 46; IV. 16, 28, 64).

Czy władza mogła być odziedziczona tylko po śmierci męża, czy też $\mathrm{w}$ jakiś sposób owe kobiety same mogły po nią sięgnąć? Trudno odpowiedzieć na to pytanie, jednakże archeologia znowu dostarcza dowodów na to, że wśród irańskojęzycznych nomadów istniały kobiety o bardzo wysokim statusie społecznym. Znane są niezwykle bogato wyposażone pochówki kobiece $\mathrm{z}$ obszaru kultur scytyjskich, czego przykładem może być datowany na VI w. p.n.e. grób tzw. „Księżniczki z Ukok” z Ałtaju (Doronin 2016: 74-76) czy pochówek z wielkiego kurhanu ryżanowskiego pochodzący z III w. p.n.e. ${ }^{6}$ (Chochorowski 1997: 77; 1999: 341). Zjawisko to jest również widoczne na tzw. „babach kamiennych”. Były to antropomorficzne stele, stawiane najczęściej na lub przy grobach i wyobrażające wybitne jednostki ${ }^{7}$. Choć $\mathrm{w}$ okresie scytyjskim najczęściej przedstawiały one mężczyzn, to jednakże zdarzały się „baby” ukazujące kobiety. Przykładem takiej steli może być „baba” z miejscowości Karaganda w północno-wschodnim Kazachstanie (Il. 4) ${ }^{8}$. Dzięki elementom stroju możemy uznać, że wyobrażała ona kobietę i została wykonana prawdopodobnie w VIII w. p.n.e. Innym ciekawym aspektem związanym z wysoko usytuowanymi kobietami ze społeczności irańskojęzycznych i innych koczowników były ich nakrycia głowy. Wiele wskazuje na to, że często nosiły one wysokie kołpaki. Davis-Kimball uważa, że takie szpiczaste czapki stanowiły nakrycia głów kapłanek ${ }^{9}$,

${ }^{6}$ Jednakże, trzeba pamiętać, że w tym przypadku był to jeden $\mathrm{z}$ dwóch pochówków z tego kurhanu. Drugi z nich był męski (Chochorowski 1997).

${ }^{7}$ Występowały one $\mathrm{w}$ różnych okresach na prawie całym obszarze Wielkiego Stepu. Najstarsze znane egzemplarze pochodzą z Europy wschodniej z okresu eneolitu, natomiast najmłodsze z terenów Syberii i są datowane na czasy niemal współczesne.

${ }^{8} \mathrm{http}$ ://en.tengrinews.kz/science/Karaganda-archaeologists-discover-Saka-eragranite-sculpture-23109/, dostęp: 03.04.2014.

${ }^{9} \mathrm{http}: / /$ workingwomen/Women Warriors/Statuses _Women_Warriors.html, dostęp: 03.04.2014. 
jednakże bardzo trudno ową hipotezę zweryfikować. Prawdopodobne jest natomiast, że były one wyznacznikiem statusu społecznego. Takie ozdoby głowy zostały stwierdzone m.in. na datowanej na IV-III w. p.n.e. mumii $\mathrm{z}$ Subeshi $\mathrm{w}$ Xinjiangu $\mathrm{w}$ zachodnich Chinach (Il. 5.A) i na głowie wspomnianej już „Księżniczki z Ukok” (Il. 5.B). Podobne nakrycia głowy zostały przedstawione na „babach kamiennych" wiązanych z Połowcami (Il. 5.C). Jednak rzeźby te datowane są na dużo późniejszy okres, bo na XII-XIII w. n.e. ${ }^{10}$ Podobne czapki pojawiały się czasem na przedstawieniach Amazonek w sztuce greckiej (Il. 2.A). Możliwe także, że posiadający również imponujące nakrycie głowy tzw. „złoty człowiek” z datowanego na IV w. p.n.e. kurhanu Esik (Issyk) w południowo-wschodnim Kazachstanie (Il. 6.A) także był kobietą. Trudności w weryfikacji tego zagadnienia przysparza fakt, że szczątki złożonej tam osoby prawie się nie zachowały. Przetrwały za to elementy stroju, które wskazują na to, że pochowana tam osoba posiadała wysoki kołpak - podobny do wymienionych powyżej przykładów. Jednak w tym wypadku trzeba zachować szczególną ostrożność, ponieważ podobne nakrycie głowy nosił wyobrażony na reliefie z Behistunu sakijski wódz Skuncha (Il. 6.B), a w sytuacji niemożliwości ustalenia płci zmarłego sprawa wydaje się nie do rozstrzygnięcia. Poza tym m.in. Herodot wspominał o scytyjskim plemieniu Orthokorybantioi ('O szpiczaste czapki" (Hdt. III. 92).

Tradycje kobiet-wojowniczek lub pamięć o nich musiały w Azji Środkowej trwać bardzo długo, ponieważ znamy przedstawienia scen batalistycznych z takimi wojowniczymi niewiastami, które datowane są na późny okres przedislamski (VI-VII w. n.e.). Zostały one uwiecznione m.in. na malowidłach w Pendżykencie. Być może czyny takich kobiet jak Sparetra, Zarina czy Tomyris dały początek wschodnioirańskim legendom i baśniom, które zostały uwiecznione na wspomnianych malowidłach i których echa można dostrzec w perskim eposie narodowym Szahname (Gafurow 1978: 284). Także w tradycji ludowej Iranu obecna jest postać Pantea Arteshbod, która to miała być rzekomo dowódcą elitarnego oddziału „Nieśmiertelnych” za czasów Cyrusa Wielkiego. Być może współczesne występowanie kobiecych oddziałów zbrojnych wśród Kurdów (np. Yekîneyên Parastina

${ }^{10}$ Jednakże patrząc na trwałość pewnych tradycji wśród ludów Wielkiego Stepu (np. stawianie „bab kamiennych” albo kurhanów), nie można wy-kluczyć, że forma czapek widoczna na niektórych połowieckich „babach kamiennych” wywodzi się ze starożytności. Być może u Połowców nosiły je również szamanki albo kapłanki, a prawie na pewno kobiety z wyżyn społecznych. 
Jin) jest reminiscencją dawnych irańskich zwyczajów, choć nie należy zapominać również o ich czysto pragmatycznym charakterze.

Wydaje się, że tradycja walczących kobiet lub pamięć o nich mogła zostać przejęta lub odziedziczona po irańskojęzycznych nomadach przez niektóre ugrupowania tureckie. Wedle jednej z legend dotyczących pochodzenia Kirgizów, mieli oni wywodzić się od córki pewnego chana oraz jej 40 kobiet-wojowniczek. Otóż wspomniane wyżej wojowniczki i córka chana wyruszyły kiedyś w podróż. Gdy z niej powróciły do rodzinnego obozu, odkryły, że wszyscy mieszkańcy zostali wymordowani. Przeżył jedynie czerwony pies (Kyzyl Taigan), z którym córka chana oraz 40 wojowniczek miały potomstwo - pierwszych Kirgizów. Ów boski, czerwony pies miał być totemicznym przodkiem Kirgizów, których nazwa miałaby pochodzić od owych 40 wojowniczek, czyli kyrk-kyz (Abramzon 1971: 191). Podobna legenda występuje wśród Karakałpaków z terenów nadaralskich. Wedle niej Gu’layım, szesnastoletnia córka władcy Alliyar, wraz ze swoimi 40 wojowniczkami-dziewicami mieszkającymi w białych jurtach broniły w XVIII w. Karakałpacji przed najazdami Kałmuków ${ }^{11}$. Być może wspomniane wyżej nakrycia głów wyobrażone na niektórych połowieckich „babach kamiennych” są również spuścizną z czasów irańskich. O tym, że w czasach tureckich obecna była nie tylko pamięć o wojowniczkach, ale również zdarzało się, że kobiety stepu same zajmowały się rzemiosłem wojennym ${ }^{12}$, może świadczyć wzmianka w Aleksjadzie Anny Komneny:

...Syn Migidena rzucił się odważnie na Pieczyngów w bitwie [...], lecz schwytany przez Scytyjkę został zawleczony żelaznym sierpem do wozów... (Komnena VII. 6).

Znamienne było użycie słowa „Scytyjka” (w odniesieniu oczywiście do uzbrojonej kobiety pieczyńskiej), które sugerowałoby, że jeszcze w średniowieczu utożsamiano, czy może bardziej kojarzono, kobietywojowniczki ze Scytami.

Podsumowując, grecki mit o Amazonkach mógł mieć swoje korzenie, przynajmniej po części, w obserwacji zwyczajów nadczarnomorskich grup irańskojęzycznych nomadów. Wśród tych ugrupowań pozycja społeczna kobiet była prawdopodobnie o wiele wyższa niż wśród Greków - miały one możliwość jazdy konnej, brały udział

${ }^{11}$ http://www.karakalpak.com/sawkele03.html\#i, dostęp: 05.05.2013.

${ }^{12}$ Choć zapewne nie na taką skalę, jak w starożytności, o czym może świadczyć mniejsza ilość źródeł na ten temat z epoki średniowiecza. 
w polowaniach i najwidoczniej, w ograniczonej formie, w walkach. Poza tym postacie charyzmatycznych koczowniczych władczyń musiały oddziaływać na wyobraźnię Greków, którzy mieli bezpośrednie kontakty z owymi wędrownymi ludami. Opowieści o nich z czasem ulegały przeobrażeniom - część z nich pozostało niedopowiedzianych, do innych dodawano fantastyczne elementy. Nakładając się na podświadomy strach przed wyzwolonymi, niezależnymi kobietami, występujący często $\mathrm{w}$ społeczeństwach patriarchalnych, opowieści te mogły dać podwaliny pod legendy o Amazonkach. Mimo że nasze możliwości poznania przeszłości są mocno ograniczone, co wynika między innymi z ograniczoności przekazów pisanych starożytnych autorów, to jednak nawet ta nikła wiedza, którą dysponujemy o kobietach w społeczeństwach starożytnych koczowników, pozwala nam nakreślić obraz fascynującego świata, gdzie płeć piękna również mogła wnieść swój heroiczny wkład do mitologii.

\section{Bibliografia}

\section{Teksty źródłowe}

Ctes. - Ktezjasz. 1986. Historia Perska (Пєрбıкó): Focjusz. 1986. Biblioteka $\left(B \imath \beta \lambda_{\imath \iota} \circ \dot{\eta} \kappa \eta\right)$. T. 1. Tłum. Oktawiusz Jurewicz. Warszawa: Instytut Wydawniczy Pax.

D.S. - Diodor Sycylijski. 1935. Library of History $\left(B \imath \beta \lambda_{\imath} \circ \theta \dot{\eta} \kappa \eta\right.$

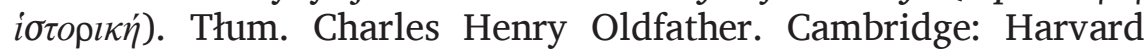
University Press.

Epitome - Marek Junianus Justynus. 1988. Zarys dziejów powszechnych starożytności na podstawie Pompejusza Trogusa (Historiae Philippicae et Totius Mundi Origines et Terrae Situs). Tłum. Ignacy Lewandowski. Warszawa: Instytut Wydawniczy PAX.

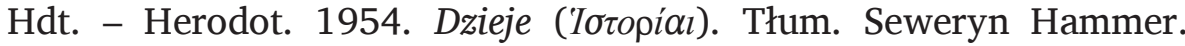
Warszawa: Czytelnik.

Hom., Il. - Homer. 1986. Iliada ('I $\lambda$ iás). Tłum. Kazimiera Jeżewska. Wrocław: Prószyński i S-ka.

Komnena - Anna Komnena. 1972. Aleksjada ( $A \lambda \varepsilon \xi \xi \dot{l} \alpha \varsigma)$. T. 2. Tłum. Oktawian Jurewicz. Wrocław: Ossolineum.

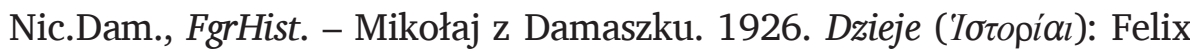
Jacoby (red.). Die Fragmente der griechischen Historiker. T. 2. Nr 90. Tłum. Karl Wilhem Ludwig Müller. Berlin: Weidmann, 324-430.

Polyaen. - Poliajnos. 2003. Podstępy wojenne ( $\Sigma \tau \rho \alpha \tau \eta \gamma \eta \dot{\mu} \alpha \tau \alpha)$. Tłum. Małgorzata Borowska. Warszawa: Prószyński i S-ka. 
Scyl. - Skylaks z Kariandy. 2005. Periplus ( $\pi \varepsilon \rho i \tau \lambda$ ovc): Periplus Sky-laksa z Karyandy. Tłum. Krzysztof Głombiowski, Zbigniew I. Brzostowski i Aleksandra Hołomej. Gdańsk: Wydawnictwo Uniwersytetu Gdańskiego.

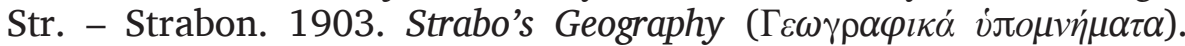
Tłum. William Falconer. Londyn: George Bell \& Sons.

\section{Artykuły i opracowania}

Abramzon, Saul Matvei. 1971. Киргизы и их этногенетические и историко-культурные связи. Biszkek: Tyрар.

Von Bothmer, Dietrich. 1957. Amazons in Greek Art. Oxford: Oxford University Press.

Brunet, Stephen. 2014. Women with Swords: Female Gladiators in the Roman World: Paul Christesen, Donald G. Kyle (red.). A Companion to Sport and Spectacle in Greek and Roman Antiquity. Chichester: Wiley Blackwell, 478-491.

Chochorowski, Jan, Skorij, Sergji, Grigorev, Vladimir, Rydzewski, Jacek. 1997. Centralny pochówek Wielkiego Kurhanu Ryżanowskiego, Materiały i Sprawozdania Rzeszowskiego Ośrodka Archeologicznego, 18 (1997), 77-92.

Chochorowski, Jan. 1999. Żelazny oręż barbarzyńców - wczesna epoka żelaza poza zasięgiem cywilizacji klasycznych: Janusz K. Kozłowski (red.). Prehistoria - encyklopedia historyczna świata. T. 1. Roz. XXII. Kraków: Agencja Publicystyczno-Wydawnicza Opres, 304-395.

Davis-Kimball, Jeannine. 1997. Warrior Women of the Eurasian Steppes, Archaeology 50, 1 (1997), 44-48.

Doronin, Dimitri Jurevič. 2016. Что опять не так с «Алтайской Принцессой»? Новые факты из ньюслорной биографии Ак Кадын, Сибирские исторические исследования, 1 (2016), 74-104.

Edmonds, Cecil John. 2010. East and West of Zagros: Travel, War and Politics in Persia and Iraq 1913-1921. Leiden: Brill.

Frisk, Hjalmar. 1970. Griechisches etymologisches Wörterbuch. T. 2. Heidelberg: Carl Winter.

Gafurow, Bobodżan. 1978. Dzieje i kultura ludów Azji Centralnej. Warszawa: Państwowy Instytut Wydawniczy.

Guliaev, Valeri I. 2003. Amazons in the Scythia: New Finds at the Middle Don, Southern Russia, World Archaeology 1, 35 (2003), 112-125.

Mayor, Adrienne. 2014. The Amazons. Lives and Legends of Warrior Women across the Ancient World. Princeton-Oxford: Princeton University Press. 
Rostovtzev, Michail Ivanovič. 1918. Эллинство и иранство на юге Poccuu. Piotrogród (Sant-Petersburg): Ogny.

\title{
Strony internetowe
}

[bez autora]. 2013. Karaganda archaeologists discover Saka-era granite sculpture, Tengri News, http://en.tengrinews.kz/science/Karaganda-archaeologistsdiscover-Saka-era-granite-sculpture-23109/, dostęp: 20.04.2014.

Richardson, David, Sue Richardson. 2006. Mythology of the Sa'wkele, http://www.karakalpak.com/sawkele03.html\#i, dostęp: 03.03.2014. Davis-Kimball, Jeannine. 2001. Statues of Sauromatian and Sarmatian Women, The Center for the Study of the Eurasian Nomads, http://www.csen.org/WomenWarriors/Statuses_Women_Warriors. html, dostęp: 04.01.2015.

\begin{abstract}
Amazons - myth or reminiscence of nomadic customs

There is evidence (archaeological, historical, linguistic, iconographic, ethnological and other mentioned in this article) to show that the formation of the myth of the Amazons could be a result of observations of habits of Iranian nomads who used to live in the areas of the northern coast of the Black Sea and Central Asia in Antiquity. Some datum indicates that women from these communities (as in many other groups of nomads) had a much higher social status than in many settled communities such as the ancient Greeks and Romans. Women in the Iranianspeaking nomadic communities were likely to participate in hunting and, to some limited extent, in fighting. In addition, some of them might have become the heads of these groups as queens (that is not as wives of kings but as independent rulers). All of it influenced the imagination of people from Greek culture who had met the nomads. Stories about these warrior women spread into Greek ecumene, increasingly evolving and subject to distortion, thus affecting the myth of the Amazons. The Amazons in Greek mythology and art often have nomadic features - they ride on horseback, wear bows and "Scythian" costumes and weapons. Tales of warlike women did not only contribute to the mythology of the ancient world, but they were inherited by Turkic-speaking groups and are still present in the culture of Iran.
\end{abstract}

Keywords: Amazons, nomads, Iranians, warriors, women. 


\section{Ilustracje}

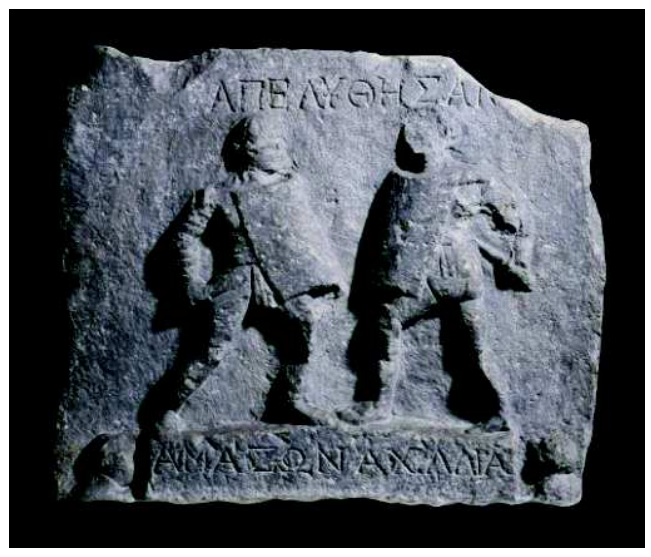

Il. 1. Przedstawienie dwóch gladiatrices (żeńskich odpowiedników gladiato-rów) na datowanym na I-II w. n.e. reliefie z Halikarnasu (dzisiejsze Bodrum), będącym obecnie częścią zbiorów British Museum. Stojąca po lewej gladiarix została podpisana imieniem Amazon, natomiast jej przeciwniczka jako Achillea.

Il. 2. Amazonki w sztuce greckiej:

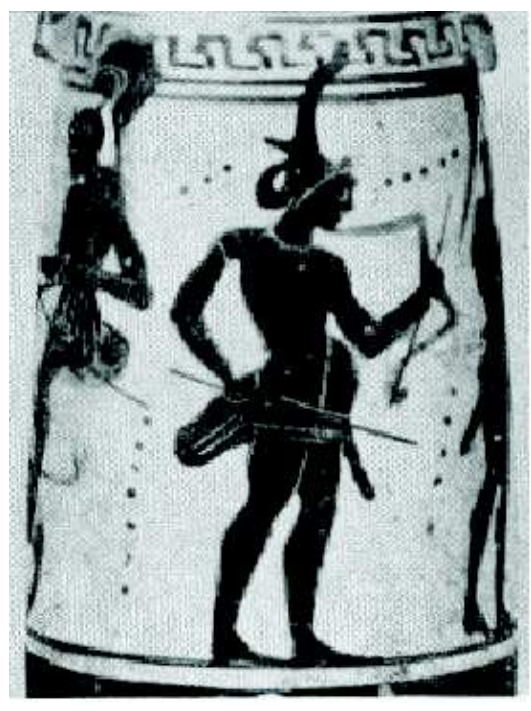

A. Na wazie czarnofigurowej. Źródło: Von Bothmer (1957: ryc. 192)

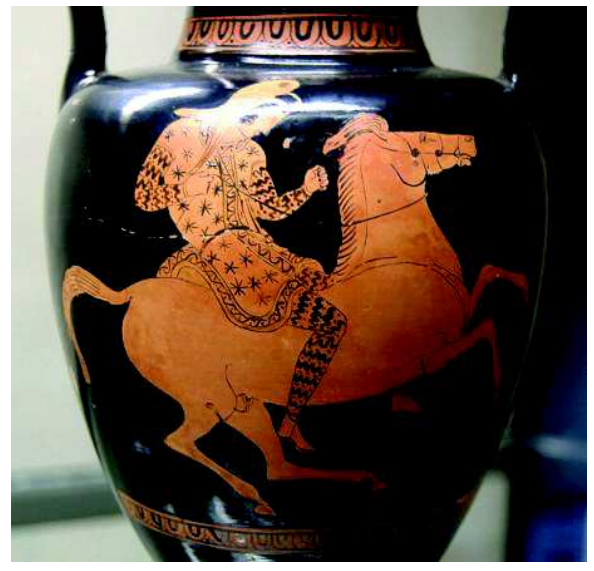

B. Na attyckiej amforze czerwonofigurowej, Mid-Manhattan Library, Nowy Jork, https://digitalcollections.nypl.org/ite ms/510d47e4-6011-a3d9-e040e00a18064a99 
Il. 3. Złoty grzebień pochodzący z datowanego na IV w. p.n.e. scytyjskiego kurhanu Soloha na Ukrainie. Powstał najprawdopodobniej $\mathrm{w}$ greckim warsztacie na zamówienie możnego Scyty. Scena figuralna na górze przedstawia walkę scytyjskich wojowników - w tym jednego uzbrojonego w tarczę typu pelta, http://twicsy.com/i/vugGUd, dostęp: 03.09.2014.

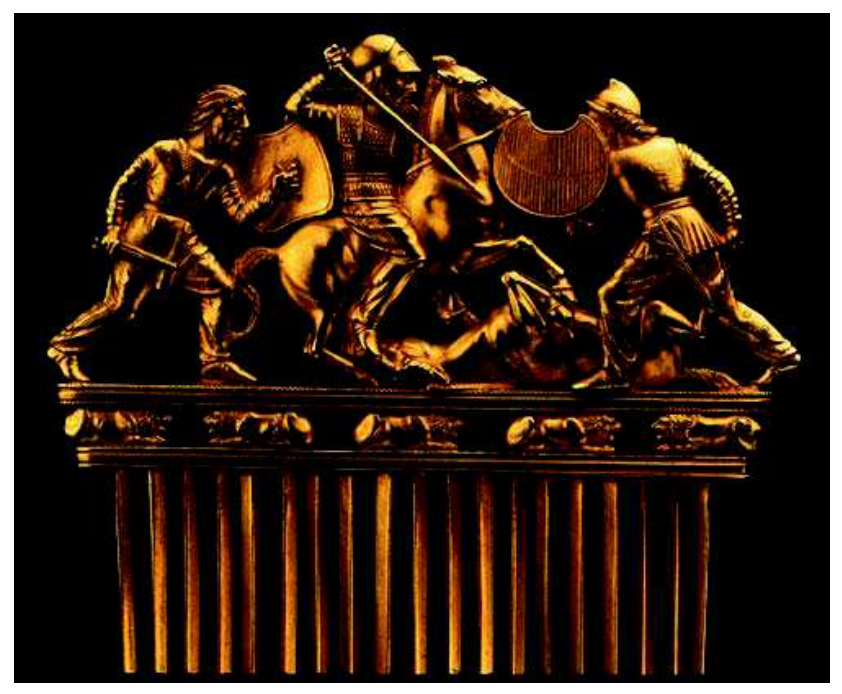

Il. 4. „Baba Kamienna” odkryta przy kurhanie sakijskim koło miejscowości Karaganda w północno-wschodnim Kazachstanie w 2013 r., http://en.tengrinews.kz/science/Karaganda-archaeologists-discover-Sakaera-granite-sculpture-23109/, dostęp: 03.09.2014.

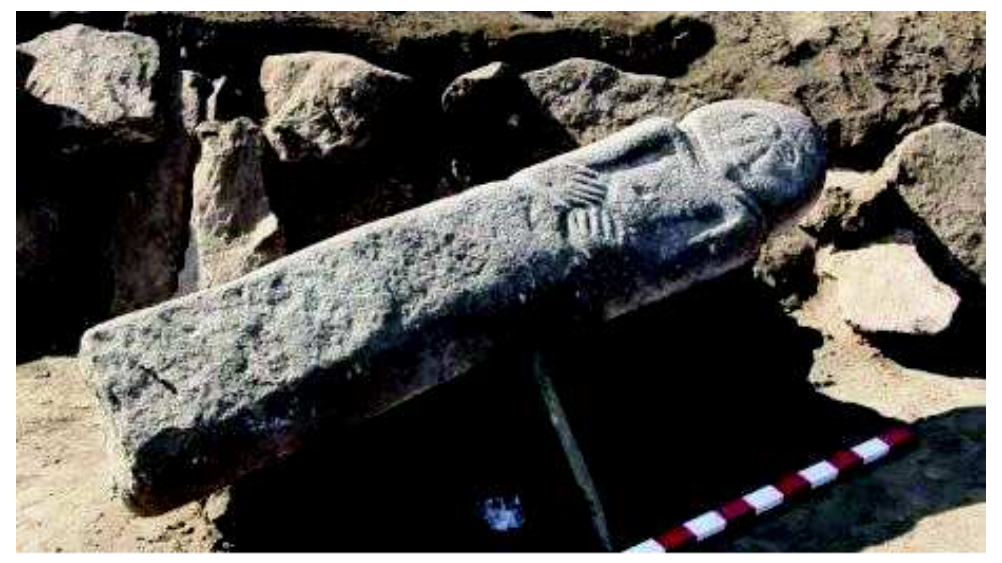


Il. 5. Wysokie nakrycia głowy kobiet stepu:

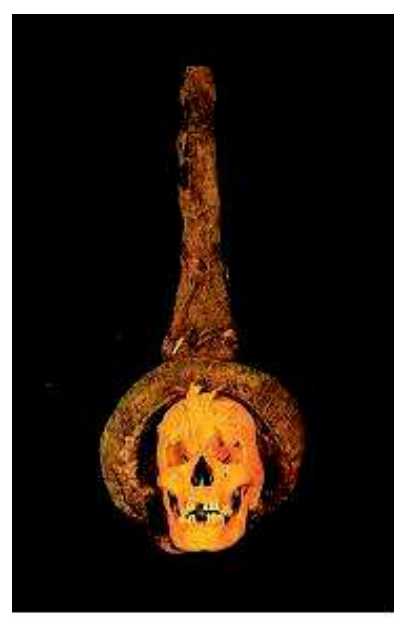

A. Subeshi (Xinjiang, Chiny),

http://califia.us/tarim/ witcheshat/witch1.htm, dostęp: 03.09.2014

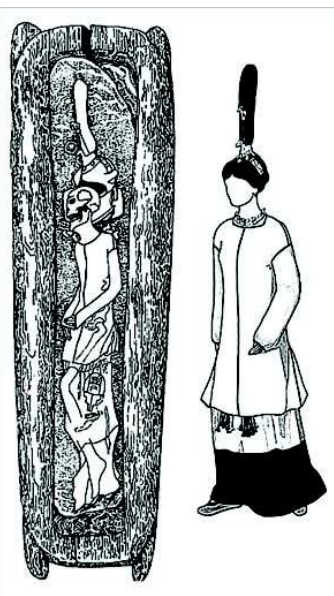

B. Ukok (Ałtaj, Rosja), http://knpradziejowe. wordpress.com/2013/ 03/22/tajemnicesyberyjskiejksiezniczki/, dostęp: 03.09.2014

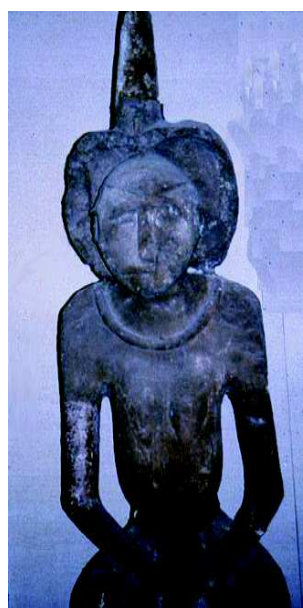

C. Połowiecka „baba kamienna". Okolice Tanais (Rostów, Rosja),http://www.csen. org/WomenWarriors/ Statuses_Women_ Warriors.html, dostęp: 03.09.2014.

Il. 6. Wysokie nakrycia głowy koczowników:

A. Tzw. „złoty człowiek” z kurhanu Issyk $\mathrm{w}$ południowo-wschodnim Kazachstanie,

http://www.csen.org/WomenWarriors/Statuses_Women_Warriors.html, dostęp: 03.09.2014.

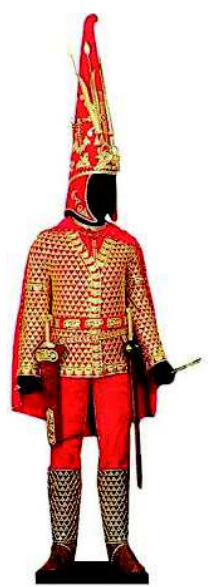


B. Relief towarzyszący inskrypcji z Behistunu w Iranie (koniec VI w. p.n.e.). Została ona stworzona, by upamiętnić zwycięstwo króla perskiego Dariusza I Wielkiego nad buntownikami, w tym wodzem sakijskim - Skunchą, który znajduje się na końcu orszaku i został wyróżniony przez autora artykułu, http://www.csen.org/WomenWarriors/Statuses_Women_Warriors.html, dostęp: 03.09.2014.
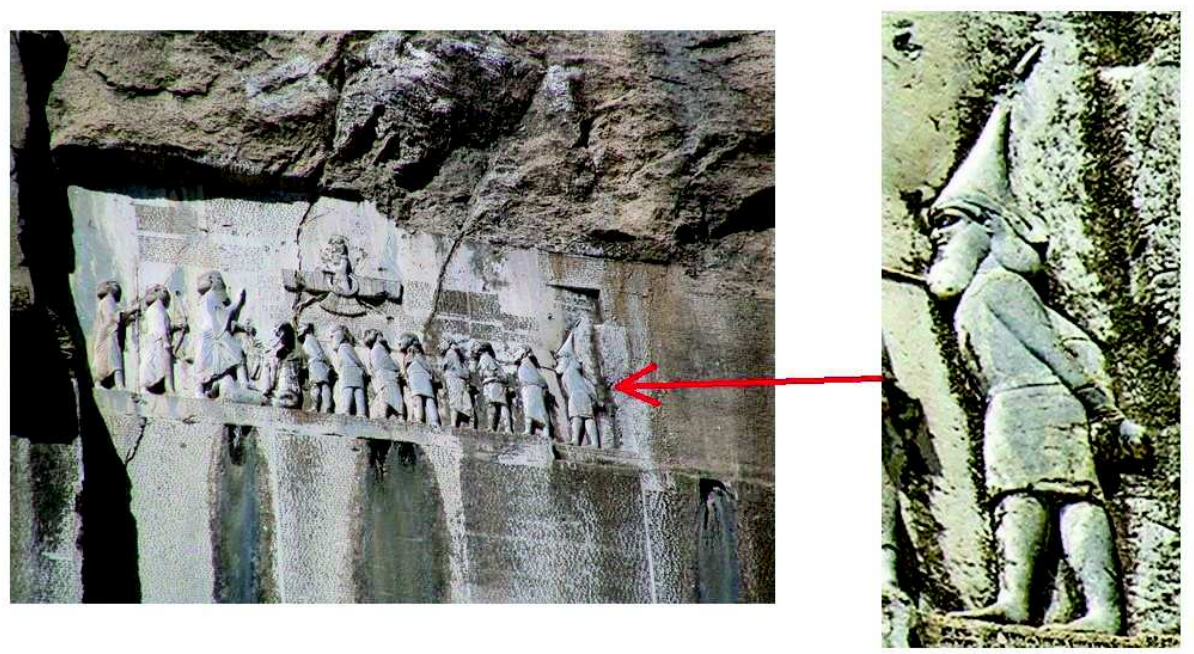